\title{
Influence of Microwave Cooking on Proximate, Mineral and Radical Scavenging Activities of Tree Bean Seeds and Pods
}

\author{
Mayengbam Premi Devi ${ }^{1,3}$, Manas Ranjan Sahoo ${ }^{1 *}$, Aparna Kuna ${ }^{2}$, Prahlad Deb ${ }^{3}$, \\ Madhumita Dasgupta ${ }^{1}$ and Narendra Prakash ${ }^{1}$ \\ ${ }^{1}$ ICAR Research Complex for North Eastern Hill Region, Lamphelpat, Imphal 795004, \\ Manipur, India \\ ${ }^{2}$ Quality Control Laboratory, PJTSAU, Hyderabad, Telangana 500030, India \\ ${ }^{3}$ Visva Bharati-A Central University, Sriniketan 731236, West Bengal, India \\ *Corresponding author
}

\section{A B S T R A C T}

\section{Keywords}

Parkiaroxburghii,

Traditional cooking,

Microwave, Radical

scavenging activities,

Nutritional properties

Article Info

Accepted:

22 July 2018

Available Online:

10 August 2018
The experiment has been carried out to investigate the proximate composition, mineral contents and radical scavenging activities (RSA) of tree bean (Parkiarox burghii G. Don) seeds and pods owing to microwave cooking and compared with that of traditional cooking. Eventually, proximate, mineral and RSA decreased significantly under both the cooking methods in comparison to the uncooked seeds and pods. However, the rate of reduction in microwave cooking was lower while compared with traditional cooking. Microwaved tree bean apparently showed better DPPH (2,2-diphenyl-2-picryl hydrazyl; 43.96-67.31\%), ABTS[2,2'-azino-bis (3-ethylbenzothiazoline-6-sulphonic acid; 57.7265.79\%] and MTT [3-(4,5-Dimethylthiazol-2-yl)-2,5-Diphenyltetrazolium Bromide; 1.19$1.53 \mathrm{Abs}$ ] activities than that of conventional cooking. Thus, microwave cooking was proven worthy in turn of retaining the nutritional properties in tree bean seeds and pods which was severely sacrificed under traditional cooking methods. The result of this study would be helpful in ensuring food and nutritional security in a sustainable way.

\section{Introduction}

Tree bean (Parkiaroxburghii G. Don) is one of the most nutritive legume grown and consumed in abundance by the people of north eastern region of India. Tender pods and seeds are rich sources of protein, carbohydrate, fat, vitamins, minerals and antioxidants compared to other realm of legumes (Singh et al., 2009; Seal, 2011). The high-quality protein content in pods and seeds may be a substitute of animal protein among the low-income people.
These legumes are consumed fresh or cooked traditionally by boiling and incorporating in different curries. Various cooking methods viz., boiling, roasting, steaming, microwave and pressure-cooking reportedly diminish nutritional properties, bioactive compounds and neutraceutical properties. In addition, cooked vegetables exhibit poor color and quality in comparison to the fresh ones (Turkmen et al., 2006). Reports showed that an appropriate process condition influences the morphological and nutritional 
characteristics of vegetable species (Bernhardt and Schlich, 2006; Podsedek, 2007). Similar studies indicated that the method of preparation and cooking can even improve the nutrition quality of food (Adriana and Guy, 2016). However, there is no information available on effect of cooking on nutritional properties of tree bean. Hence, the present experiment was conducted in order to study the effect of conventional and microwave cooking on proximate, mineral and radical scavenging activities of tree bean (Parkiaroxburghii G. Don).

\section{Materials and Methods}

\section{Crop material and treatment conditions}

Tree bean pods were collected from the local market of Imphal, Manipur, India. Uniform, fresh and matured green pods free from mechanical injury were selected for the experiment and cleaned properly before cooking treatments. Matured pods were scrapped and cut into pieces. Seeds were also collected from the pods and studies for the nutritional changes owing to cooking.

For conventional cooking, a set of pod pieces and seeds (100 gm) were boiled in $200 \mathrm{ml}$ water for $5 \mathrm{~min}$ and another set for $10 \mathrm{~min}$. In case of microwave cooking, two sets of bean pieces (100 gm each) were microwaved at 600 $\mathrm{W}$ and $1000 \mathrm{~W}$ for $3 \mathrm{~min}$ each. Excess moisture of the cooked bean was decanted and soaked in blotting paper. Proximate composition, mineral composition and free radical scavenging activities were analyzed in three replicates with duplicate determinations.

\section{Analyses}

\section{Proximate analysis}

Moisture, ash, crude fat, crude fibre, crude protein, nitrogen free extracts and energy of the cooked and uncooked tree bean were determined according to the AOAC (2012) methods.

\section{Mineral content}

Nitrogen content was determined by Kjeldahl's method. Other minerals were analysed after wet ashing by concentrated nitric acid and perchloric acid (1:1, v/v). Mineral contents viz., iron $(\mathrm{Fe})$, zinc $(\mathrm{Zn})$, calcium $(\mathrm{Ca})$, magnesium $(\mathrm{Mg})$, copper $(\mathrm{Cu})$ and manganese $(\mathrm{Mn})$ were analyzed by atomic absorption spectrometry whereas; sodium $(\mathrm{Na})$ and potassium $(\mathrm{K})$ were estimated by flame photometry and phosphorus (P) using spectrophotometry, according to the methods of AOAC (2012).

\section{Radical scavenging activities and MTT assay}

\section{Extraction}

Samples $(10 \mathrm{~g})$ were extracted with $100 \mathrm{ml}$ of aqueous methanol (80\%, v/v) at ambient temperature with agitation for 18-24 hr.

The extracts were filtered using Whatman No. 1 filter paper and the filtrates were separately concentrated to dryness by using a rotary evaporator (Buchi, Switzerland) and aliquots $(10 \mathrm{mg} / \mathrm{ml})$ were analysed for free radical scavenging activity and MTT activity.

\section{DPPH (2,2-diphenyl-2-picryl hydrazyl)}

DPPH activity was examined as according to Blois (1958).

Solution mixtures of $100 \mu \mathrm{l}$ of sample extracts and $3.9 \mathrm{ml}$ of $0.5 \mathrm{mM}$ DPPH were incubated for $30 \mathrm{~min}$ at $25^{\circ} \mathrm{C}$ in dark. The discolourisation of the purple colour was measured at $518 \mathrm{~nm}$ and percent scavenging activity was calculated. 


\section{ABTS [2,2'-azino-bis thiazoline-6-sulphonic acid] \\ (3-ethylbenzo-}

ABTS was determined by using the method of Re et al., (1999). ABTS radical cations (ABTS+) were produced by reacting ABTS solution $(7 \mathrm{mM})$ with $2.45 \mathrm{mM}$ ammonium per sulphate (kept in the dark for 12-16 hrs before use). The absorbance was read at 745 $\mathrm{nm}$ after $10 \mathrm{~min}$ after adding $20 \mu \mathrm{l}$ extract to $980 \mu \mathrm{l}$ of ABTS solution and the per cent inhibition was calculated.

MTT [3-(4,5-Dimethylthiazol-2-yl)-2,5-Diphenyltetrazolium Bromide]

MTT assay was carried out using the protocol derived by Lui and Nair (2010) with some modifications. Stock solutions of extracts were prepared in DMSO at $40 \mathrm{mg} / \mathrm{ml}$ and MTT was dissolved in water at $0.5 \mathrm{mg} / \mathrm{ml}$. The two solutions were added in a glass vial at $1: 1 \mathrm{v} / \mathrm{v}$ and mixed thoroughly for $1 \mathrm{~min}$. The reaction mixture was then incubated at $37^{\circ} \mathrm{C}$ for $6 \mathrm{hr}$. The absorbance was measured at $570 \mathrm{~nm}$. Ascorbic acid, Gallic acid and Trolox were used as positive control.

\section{Statistical analyses}

The experiment was conducted in completely randomized design (CRD). The data were analysed statistically following the analysis of variance (ANOVA) and significance was tested at probability level $\mathrm{P} \leq 0.01$. All data represented are mean of three replications with duplicate determinations.

\section{Results and Discussion}

\section{Effect of microwave cooking on proximate composition of tree bean}

Table 1 showed that moisture content in tree bean pods and seeds under conventional and microwave cooking was significantly higher than uncooked control, which is in accordance to the findings of Lewu et al., (2009). However, ash, crude fat, crude fibre, crude protein and energy showed a decreasing trend under cooking either ways. Microwave cooked tree bean seed at $600 \mathrm{~W}$ appeared to be with higher ash content $3.43 \%$ in seeds and $4.20 \%$ in pods) among the cooking treatments with lower decrease over uncooked control (Table 1). Similarly, crude fibre $(9.74 \%$ in seeds and $5.53 \%$ in pods) and crude protein $(4.96 \%$ in seeds and $2.51 \%$ in pods) was less affected under microwave cooking at $600 \mathrm{Wwhile}$ compared with control (Table 1). On the contrary, fat content (1.13-1.37\% in seeds and $0.35-0.88 \%$ in pods) was highly decreased under microwave cooking in comparison to conventional cooking (Table 1). The decrease in proximate content could be due to diffusion of the contents into cooking water (Alajaji and El-Adawy, 2006). However, nitrogen free extracts and energy showed non-significant differences among the cooking treatments in this study although there was a significant variation between the cooked and uncooked tree bean samples. Similar observations were reported inIrish and Sweet potato (Ikanone and Oyeka, 2014). Proximate content was found to be significantly affected by cooking procedure depending on the individual compounds (Hwang et al., 2012). Overall results indicated that microwave cooking at 600W exhibits comparatively higher proximate compositions in tree bean among all the cooking treatments.

\section{Effect of microwave cooking on Mineral composition of tree bean}

Mineral contents (N, P, K, Na, Ca, Mg, Fe, $\mathrm{Zn}, \mathrm{Cu}$ and $\mathrm{Mn}$ ) in cooked tree bean were significantly decreased while compared with uncooked samples (Table 2). The rate of decrease in mineral contents was comparatively lower at microwave cooking at $600 \mathrm{~W}$ followed by $1000 \mathrm{~W}$. 
Table.1 Proximate composition of tree bean seeds and pods as influenced by traditional and microwave cooking

\begin{tabular}{|c|c|c|c|c|c|c|c|}
\hline Treatments & $\begin{array}{c}\text { Moisture } \\
\text { content }(\%)\end{array}$ & $\begin{array}{c}\text { Ash } \\
\text { content } \\
(\%)\end{array}$ & $\begin{array}{l}\text { Crude } \\
\text { Fat }(\%)\end{array}$ & $\begin{array}{c}\text { Crude } \\
\text { Fibre }(\%)\end{array}$ & $\begin{array}{c}\text { Crude } \\
\text { Protein }(\%)\end{array}$ & NFE (\%) & $\begin{array}{c}\text { Energy } \\
\text { (Kcal/g FW) }\end{array}$ \\
\hline Uncooked seeds & $62.59 \pm 3.57$ & $3.80 \pm 0.44$ & $5.82 \pm 0.18$ & $5.63 \pm 1.36$ & $8.23 \pm 0.35$ & $13.93 \pm 4.50$ & $140.98 \pm 18.00$ \\
\hline Traditional cooked seeds (10 min) & $79.05 \pm 1.75$ & $2.50 \pm 0.46$ & $1.62 \pm 0.68$ & $8.73 \pm 1.01$ & $4.67 \pm 0.27$ & $3.43 \pm 2.87$ & $46.99 \pm 8.05$ \\
\hline Traditional cooked seeds (20 min) & $81.33 \pm 4.28$ & $2.33 \pm 0.29$ & $1.82 \pm 0.56$ & $4.47 \pm 0.42$ & $3.97 \pm 0.27$ & $6.09 \pm 3.98$ & $56.58 \pm 20.50$ \\
\hline MW cooked $(600 W)$ seeds & $76.33 \pm 1.75$ & $3.43 \pm 0.45$ & $1.37 \pm 0.71$ & $9.74 \pm 4.05$ & $4.96 \pm 0.27$ & $4.17 \pm 5.47$ & $48.83 \pm 26.33$ \\
\hline MW cooked(1000W) seeds & $78.61 \pm 4.28$ & $3.37 \pm 0.83$ & $1.13 \pm 0.32$ & $6.26 \pm 3.16$ & $4.67 \pm 0.36$ & $5.97 \pm 5.73$ & $52.73 \pm 18.68$ \\
\hline Uncooked pods & $58.55 \pm 1.22$ & $4.70 \pm 0.53$ & $2.08 \pm 1.13$ & $13.73 \pm 0.45$ & $4.67 \pm 0.44$ & $16.26 \pm 0.80$ & $102.47 \pm 8.49$ \\
\hline Traditional cooked pods (10 min) & $76.43 \pm 3.15$ & $4.13 \pm 0.91$ & $0.73 \pm 0.28$ & $7.57 \pm 4.60$ & $2.16 \pm 0.20$ & $8.98 \pm 5.83$ & $51.13 \pm 24.56$ \\
\hline Traditional cooked pods (20 min) & $71.15 \pm 10.55$ & $2.93 \pm 0.85$ & $0.73 \pm 0.33$ & $6.50 \pm 0.75$ & $2.10 \pm 0.17$ & $16.58 \pm 11.09$ & $81.32 \pm 45.48$ \\
\hline MW cooked(600W) pods & $73.71 \pm 3.15$ & $4.20 \pm 0.52$ & $0.88 \pm 0.53$ & $5.53 \pm 1.63$ & $2.51 \pm 0.36$ & $13.16 \pm 4.31$ & $70.63 \pm 17.67$ \\
\hline MW cooked(1000W) pods & $68.43 \pm 10.55$ & $3.83 \pm 0.93$ & $0.35 \pm 0.35$ & $5.93 \pm 2.55$ & $2.39 \pm 0.20$ & $19.06 \pm 13.77$ & $88.95 \pm 53.37$ \\
\hline SEm & 3.16 & 0.38 & 0.33 & 1.42 & 0.17 & 3.97 & 16.08 \\
\hline CD (0.05) & 9.32 & 1.12 & 0.97 & 4.19 & 0.51 & NS & 47.42 \\
\hline $\mathrm{CD}(0.01)$ & 12.71 & 1.53 & 1.33 & 5.71 & 0.70 & NS & NS \\
\hline
\end{tabular}

All data is mean of three replicates with duplicate determinations. Different letters represent significant difference $(\mathrm{P} \leq 0.01)$ among the treatments according to Duncan's multiple range test (DMRT). 
Table.2 Mineral contents of tree bean seeds and pods as influenced by traditional and microwave cooking

\begin{tabular}{|c|c|c|c|c|c|c|c|c|c|c|}
\hline Treatments & $\begin{array}{c}\mathrm{N} \\
(\%)\end{array}$ & $\begin{array}{c}\mathbf{P} \\
(\mathrm{ppm})\end{array}$ & $\begin{array}{c}\mathrm{K} \\
(\mathrm{ppm})\end{array}$ & $\begin{array}{c}\mathrm{Na} \\
(\mathbf{p p m})\end{array}$ & $\begin{array}{c}\text { Ca } \\
(\mathrm{ppm})\end{array}$ & $\begin{array}{c}\text { Mg } \\
(\mathrm{ppm})\end{array}$ & $\begin{array}{c}\mathrm{Fe} \\
(\mathrm{ppm})\end{array}$ & $\begin{array}{c}\mathrm{Zn} \\
(\mathbf{p p m})\end{array}$ & $\begin{array}{c}\mathrm{Cu} \\
(\mathbf{p p m})\end{array}$ & $\begin{array}{c}\mathrm{Mn} \\
(\mathrm{ppm})\end{array}$ \\
\hline $\begin{array}{l}\text { Uncooked } \\
\text { seeds }\end{array}$ & $1.32 \pm 0.06$ & $85.69 \pm 7.02$ & $1568.0 \pm 121.24$ & $303.33 \pm 2.89$ & $1424.08 \pm 199.06$ & $102.08 \pm 7.09$ & $82.02 \pm 3.72$ & $1.45 \pm 0.10$ & $11.33 \pm 1.10$ & $6.67 \pm 0.29$ \\
\hline $\begin{array}{l}\text { Traditional } \\
\text { cooked seeds } \\
(10 \text { min) } \\
\end{array}$ & $0.75 \pm 0.04$ & $21.37 \pm 2.23$ & $966.0 \pm 46.86$ & $208.33 \pm 11.55$ & $533.93 \pm 72.88$ & $73.22 \pm 1.83$ & $4.88 \pm 0.53$ & $0.63 \pm 0.10$ & $2.38 \pm 0.34$ & $1.92 \pm 0.20$ \\
\hline $\begin{array}{l}\text { Traditional } \\
\text { cooked seeds } \\
(20 \mathrm{~min}) \\
\end{array}$ & $0.63 \pm 0.04$ & $20.00 \pm 1.76$ & $868.0 \pm 69.54$ & $188.33 \pm 2.89$ & $477.15 \pm 73.85$ & $71.53 \pm 5.23$ & $3.27 \pm 0.49$ & $0.38 \pm 0.03$ & $1.65 \pm 0.28$ & $1.13 \pm 0.33$ \\
\hline $\begin{array}{l}\text { MW } \\
\text { cooked(600W) } \\
\text { seeds }\end{array}$ & $0.79 \pm 0.04$ & $54.31 \pm 0.90$ & $1514.0 \pm 336.50$ & $258.33 \pm 11.55$ & $798.97 \pm 58.11$ & $88.22 \pm 1.83$ & $6.77 \pm 2.82$ & $1.02 \pm 0.13$ & $2.72 \pm 1.05$ & $3.18 \pm 0.87$ \\
\hline $\begin{array}{l}\text { MW } \\
\text { cooked(1000W) } \\
\text { seeds }\end{array}$ & $0.75 \pm 0.06$ & $32.35 \pm 1.56$ & $1102.0 \pm 141.01$ & $238.33 \pm 2.89$ & $688.80 \pm 174.01$ & $86.53 \pm 5.23$ & $5.62 \pm 2.94$ & $0.78 \pm 0.03$ & $2.32 \pm 1.34$ & $2.17 \pm 0.75$ \\
\hline Uncooked pods & $0.75 \pm 0.07$ & $90.39 \pm 10.30$ & $2428.0 \pm 55.75$ & $300.00 \pm 13.23$ & $1405.80 \pm 82.49$ & $94.77 \pm 1.18$ & $36.87 \pm 7.79$ & $1.40 \pm 0.30$ & $6.95 \pm 0.25$ & $4.85 \pm 0.49$ \\
\hline $\begin{array}{l}\text { Traditional } \\
\text { cooked pods } \\
(10 \mathrm{~min}) \\
\end{array}$ & $0.35 \pm 0.03$ & $35.49 \pm 2.45$ & $1644.0 \pm 156.92$ & $175.00 \pm 10.00$ & $539.50 \pm 42.72$ & $68.73 \pm 4.33$ & $6.17 \pm 1.91$ & $0.48 \pm 0.10$ & $1.35 \pm 0.39$ & $1.55 \pm 0.35$ \\
\hline $\begin{array}{l}\text { Traditional } \\
\text { cooked pods } \\
(20 \mathrm{~min}) \\
\end{array}$ & $0.34 \pm 0.03$ & $27.06 \pm 1.56$ & $966.0 \pm 46.86$ & $171.67 \pm 7.64$ & $399.60 \pm 70.06$ & $64.13 \pm 2.33$ & $4.87 \pm 1.38$ & $0.35 \pm 0.05$ & $0.62 \pm 0.25$ & $1.50 \pm 0.13$ \\
\hline $\begin{array}{l}\text { MW } \\
\text { cooked(600W) } \\
\text { pods }\end{array}$ & $0.40 \pm 0.06$ & $44.51 \pm 1.48$ & $2074.0 \pm 225.88$ & $225.00 \pm 10.00$ & $758.67 \pm 150.28$ & $82.07 \pm 2.39$ & $7.33 \pm 0.20$ & $0.87 \pm 0.13$ & $1.65 \pm 0.30$ & $2.98 \pm 0.28$ \\
\hline $\begin{array}{l}\text { MW } \\
\text { cooked(1000W) } \\
\text { pods }\end{array}$ & $0.38 \pm 0.03$ & $40.59 \pm 2.35$ & $1890.0 \pm 421.03$ & $223.33 \pm 7.64$ & $510.95 \pm 21.87$ & $75.80 \pm 3.88$ & $4.68 \pm 1.10$ & $0.77 \pm 0.20$ & $1.53 \pm 0.73$ & $1.83 \pm 0.19$ \\
\hline SEm & 0.03 & 2.47 & 117.34 & 5.11 & 63.42 & 2.29 & 1.81 & 0.08 & 0.42 & 0.26 \\
\hline CD (0.05) & 0.08 & 7.28 & 346.11 & 15.07 & 187.05 & 6.77 & 5.34 & 0.24 & 1.23 & 0.77 \\
\hline CD (0.01) & 0.11 & 9.93 & 472.04 & 20.56 & 255.11 & 9.23 & 7.29 & 0.33 & 1.67 & 1.05 \\
\hline
\end{tabular}


Table.3 Effect of traditional and microwave cooking on radical scavenging activitiesand MTT assay of tree bean

\begin{tabular}{|l|c|c|c|}
\hline Treatments & $\begin{array}{c}\text { DPPH } \\
\text { (\% activity) }\end{array}$ & $\begin{array}{c}\text { ABTS } \\
(\% \text { activity })\end{array}$ & MTT (Abs) \\
\hline Uncooked seeds & $83.07 \pm 1.14$ & $53.66 \pm 1.90$ & $2.04 \pm 0.09$ \\
\hline Traditional cooked seeds (10 $\mathbf{m i n})$ & $52.23 \pm 0.83$ & $41.86 \pm 9.88$ & $1.20 \pm 0.05$ \\
\hline Traditional cooked seeds (20 $\mathbf{m i n})$ & $41.18 \pm 0.70$ & $28.80 \pm 10.33$ & $1.27 \pm 0.08$ \\
\hline MW cooked(600W) seeds & $54.32 \pm 2.20$ & $65.79 \pm 1.74$ & $1.32 \pm 0.07$ \\
\hline MW cooked(1000W) seeds & $43.96 \pm 1.04$ & $57.72 \pm 0.97$ & $1.53 \pm 0.12$ \\
\hline Uncooked pods & $89.51 \pm 0.50$ & $68.56 \pm 2.44$ & $2.67 \pm 0.28$ \\
\hline Traditional cooked pods (10 min) & $52.76 \pm 0.87$ & $63.73 \pm 8.05$ & $1.49 \pm 0.11$ \\
\hline Traditional cooked pods (20 min) & $30.59 \pm 1.59$ & $54.39 \pm 2.58$ & $0.91 \pm 0.06$ \\
\hline MW cooked(600W) pods & $67.31 \pm 1.17$ & $64.21 \pm 0.63$ & $1.53 \pm 0.08$ \\
\hline MW cooked(1000W) pods & $45.21 \pm 0.68$ & $58.92 \pm 1.13$ & $1.19 \pm 0.09$ \\
\hline SEm & 0.68 & 3.12 & 0.07 \\
\hline CD (0.05) & 2.00 & 9.19 & 0.20 \\
\hline CD (0.01) & 2.72 & 12.53 & 0.28 \\
\hline
\end{tabular}

Higher degradation in mineral compositions was observed in traditional cooking for 20 minutes followed by cooking for 10 minutes. Cooking suppresses the mineral content in vegetables which may be minimized for ensuring better nutritive values in foods (Onyeike et al., 2003; Alajaji et al., 2006; Ikanone and Oyeka, 2014). Ash content represents nutritionally important minerals in food materials, hence, reduction of essential mineral in the food coupled with decrease in ash content under cooking (Onyeike and Oguike, 2003). Microwave cooking possessed greater retention of all minerals than that of boiling in various vegetables (Alajaji and ElAdawy, 2006), which is similar to the result of this experiment.

\section{Effect of microwave cooking on radical scavenging and MTT activity of tree bean}

DPPH activity in tree bean seeds and pulps was decreased in both traditional and microwave cooking while compared with uncooked samples. It is noteworthy that, microwave cooking at $600 \mathrm{~W}$ had higher
DPPH activities $(54.32 \%$ in seeds and 67.31 in pods) among the cooking treatments (Table 3 ). Conventional cooking method by boiling led to detrimental effect in DPPH activity (Chuah et al., 2008). Ilyasoğlu and Burnaz (2015) reported microwave cooking as a better cooking process as compared to the traditional boiling treatment. Antioxidant capacities depend on the cooking procedures and vegetable structure (Ozyurt and Goc, 2013). Ng et al., 2011 reported that decreased in DPPH radical scavenging activity is correlated with the degradation of phenolic compounds owing to cooking.

Cooking for longer duration decreased radical scavenging activities such as DPPH and ABTS activities. ABTS activity was significantly higher in the seeds $(65.79 \%)$ and pods $(64.21 \%)$ while cooked in microwave at $600 \mathrm{~W}$ which was observed to be lower in traditional boiling for 20 minutes (Table 3). Jiménez- Monreal et al., (2009) reported that microwave cooking led to lowest losses in radical scavenging assay and boiling for longer time lead to highest loss. According to 
Hwang et al., (2012), cooking factors, including method, temperature, cooking time, and portion size, strongly affects the antioxidant activities in food.

MTT assay is a colorimetric assay for assessing cell metabolic activity which observed to be decreased both in traditional and microwave cooking processes. The activity appeared to be better in microwaved seeds (1.53 Abs at $1000 \mathrm{~W}$ followed by 1.32 Abs at $600 \mathrm{~W})$ and pods (1.53 Abs at 600W) compared to that of uncooked pulp (Table 3). The least MTT activity was observed in conventional cooking (0.91-1.49 Abs). Previous studies indicated that antioxidant capacities of vegetables were decreased under thermal treatments (Ismail et al., 2004; Roy et al., 2007; Podsedek, 2007; Faller and Fialho, 2009). Inactivation of antioxidant compounds due thermal treatment could be the probable reason for decreased assays (Turkmen et al., 2005; Faller and Fialho, 2009).

Robinson et al., 2017 reported that antioxidant and free radical scavenging activity of the extract influences its anticancer properties which indicate that microwave cooking might be leading to have better antioxidant and cell metabolic activities as compared to other cooking methods.

In this study, microwave cooking exhibited comparatively better proximate composition, mineral contents and radical scavenging activities in tree bean seeds and pods over traditional cooking methods. Cooking by traditionally boiling techniques for longer duration resulted in maximum loss of nutrients. Hence, it could be concluded that microwave cooking not only saves time but also effectively retains the nutritive values in the food. The result of this study shed light on preventing nutritional loss in dietary supplements with appropriate cooking methods.

\section{References}

Adriana, D.T.F., and Guy, A.C. 2016. A review of the impact of preparation and cooking on the nutritional quality of vegetables and legumes. International Journal of Gastronomy and Food Science. 3: 2-11.

Alajaji, S.A., and El-Adawy, T.A. 2006. Nutritional composition of chickpea (Cicer arietinum L.) as affected by microwave cooking and other traditional cooking methods. Journal of Food Composition and Analysis. 19(8): 806-812.

AOAC, 2012. Official methods of analysis, $19^{\text {th }}$ ed. Association of official analytical chemists, Washington D.C., USA.

Bernhardt, S., and Schlich, E. 2006. Impact of different cooking methods on food quality: retention of lipophilic vitamins in fresh and frozen vegetables. J. Food Eng. 77: 327-333.

Blois, M.S., 1958. Antioxidant determinations by the use of a stable free radical. Nature. 181: 1199-1200. doi: 10.1038/1811199a0

Chuah, A.M., Y.C. Lee, T. Yamaguchi, H. Takamura, L.J. Yin, and Matoba, T. 2008. Effect of cooking on the antioxidant properties of coloured peppers. Food Chem.111: 20-28.

Faller, A.L.K., and Fialho, E. 2009. The antioxidant capacity and polyphenol content of organic and conventional retail vegetables after domestic cooking. Food Res. Int. 42:210-215.

Hwang, I.G., Shin, Y.J., Lee, S., Lee, J., and Yoo, S.M. 2012. Effects of Different Cooking Methods on the Antioxidant Properties of Red Pepper. Prev. Nutr. Food Sci. 17: 286-292.

Ikanone, C.E.O., and Oyeka, P.O. 2014. Effect of Boiling and Frying on the Total Carbohydrate, Vitamin $\mathrm{C}$ and 
Mineral Contents of Irish (Solanum tuberosum) and Sweet (Ipomeabatatas) Potato Tubers. Nigerian Food Journal. 32: 2 .

Ilyasoğlu, H., and Burnaz, N.A. 2015. Effect of Domestic Cooking Methods on Antioxidant Capacity of Fresh and Frozen Kale. International Journal of Food Properties. 18(6): 1298-1305.

Ismail, A., Marjan, Z.M., and Foong, C.W. 2004. Total antioxidant activity and phenolic content in selected vegetables. Food Chem. 87: 581-586.

Jimenez-Monreal, A.M., Garcia-Diz, L., Martinez-Tome, M., Mariscal, M., and Murcia, M.A. 2009. Influence of cooking methods on antioxidant activity of vegetables. J. Food Sci. 74: H97H103.

Lewu, M.N., Adebola, P.O. and Afolayan, A.J. 2009. Effect of cooking on the proximate composition of the leaves of some accessions of Colocasia esculenta (L.) Schott in KwaZulu-Natal province of South Africa.African Journal of Biotechnology. 8 (8): 1619-1622.

Lui, Y., and Nair, M.G. 2010. An efficient and economical MTT assay for determining the antioxidant activity of plant natural product extracts and pure compounds. J. Nat. Prod. 73 (7): 1193 5.

Ng, Z.X., Chai, J.W. and Kuppusamy, U.R. 2011. Customized cooking method improves total antioxidant activity in selected vegetables. International Journal of Food Sciences and Nutrition. 62(2): 158-163.

Onyeike, E.N., and Oguike, J.U. 2003. Influence of heat processing methods on the nutrient composition and lipid characterization of groundnut (Arachis hypogaea) seed pastes. Biokemistri. 15(1): 34-43.

Onyeike, E.N., Ihugba, A.C. and Chinyere, G. 2003. Influence of heat processing on the nutrient composition of vegetable leaves consumed in Nigeria. Plant Foods for Human Nutrition. 58(3): 111.

Ozyurt, D., Goc, B., Demirata, B., and Apak, R. 2013. Effect of oven and microwave heating on the total antioxidant capacity of dietary onions grown in Turkey. International Journal of Food Properties. 16: 536-548.

Podsedek, A. 2007. Natural antioxidants and antioxidant capacity of Brassica vegetables: A review. LWT Food Sci. Technol. 40: 1-11.

Re, R., Pellegrini, N., Proteggente, A., Pannala, A., Yang, M., and Rice-Evans, C. 1999. Antioxidant activity applying an improved ABTS radical cation decolorization assay. Free Radic. Biol. Med. 26:1231-1237. doi:10.1016/S0891-5849(98)00315-3

Robinson, J.P., Suriya, K., Subbaiya, R., and Ponmurugan, P. 2017. Antioxidant and cytotoxic activity of Tecomastans against lung cancer cell line (A549). Brazilian Journal of Pharmaceutical Sciences. 53(3).

Roy, M.K., Takenaka, M., Isobe, S., and Tsushida, T. 2007. Antioxidant potential, anti-proliferative activities, and phenolic content in water-soluble fractions of some commonly consumed vegetables: Effects of thermal treatment. Food Chem. 103: 106-114.

Seal, T., 2011. Nutritional Composition of Wild Edible Fruits in Meghalaya State of India and Their Ethno-botanical Importance. Res. J. Bot. 6:58-67. doi:10.3923/rjb.2011.58.67

Singh, S.J., Singh, P.K., Dutta, B.K., and Sahoo, U.K. 2009. Chemical composition and nutritive indices in Parkiaroxburghii g. don, a leguminous plant of India. Indian Journal of Agricultural Biochemistry. 22(2): 8793. 
Turkmen, N., Poyrazoglu, E.S., Sari, F., and Velioglu, Y.S. 2006. Effects of cooking methods on chlorophylls, pheophytins and colour of selected green vegetables. Int. J. Food Sci. Technol. 41: 281-288.
Turkmen, N., Sari, F., and Velioglu, Y.S. 2005. The effect of cooking methods on total phenolics and antioxidant activity of selected green vegetables. Food Chem. 93: 713-718.

\section{How to cite this article:}

Mayengbam Premi Devi, Manas Ranjan Sahoo, Aparna Kuna, Prahlad Deb, Madhumita Dasgupta and Narendra Prakash. 2018. Influence of Microwave Cooking on Proximate, Mineral and Radical Scavenging Activities of Tree Bean Seeds and Pods. Int.J.Curr.Microbiol.App.Sci. 7(08): 3909-3917. doi: https://doi.org/10.20546/ijcmas.2018.708.402 